\title{
Island geopoetics and the postcolonial discourse of Sardinia in German-language literature
}

\author{
Valentina Serra \\ Università degli Studi di Cagliari - Italy \\ vserra@unica.it
}

\begin{abstract}
From the second half of the 17th century onwards, Sardinia has fascinated many German-speaking travelers and writers, whose works have given rise to a particular literary tradition, based on a prismatic image of this island. Through a large and often unexplored corpus, consisting of travelogues, diaries, novels, short stories, and poetry, a specific literary discourse of the island has been constructed over the centuries, and Sardinia has acquired the distorted image of either a waste land, an exile, and prison, or an uncorrupted paradise, where human beings can still retrieve a deep relationship with the Earth. This paper aims to give an account of this discourse to highlight, from a diachronic perspective, the construction of the image of an island more or less influenced by a Eurocentric perspective. Using a geopoetic approach, several texts are analysed in a hermeneutic process which outlines not only the island's colonial past, but also the construction of a recent neocolonial project made up of uncontrolled urbanization, industrialization, mass tourism, and (nuclear) pollution.
\end{abstract}

Keywords: Ernst Jünger, geopoetics, German-language literature, islands, postcolonial discourse, Sardinia

https://doi.org/10.24043/isj.39

(C) 2017 — Institute of Island Studies, University of Prince Edward Island, Canada.

\section{Introduction}

Since the second half of the 17th century, Sardinia, the second-largest island of the Mediterranean, has been the topic of many fictional and non-fictional works, which have contributed to what in this paper will be regarded as the construction of the island's specific literary discourse (Dongu 2012). In these literary works, which constitute a large and often unexplored corpus, Sardinia acquires countless forms and representations and, like many of the world's other islands, has been described "as refuge or as prison, as paradise or as inferno, as child, or as a chip off the old block of the mainland" (McCusker \& Soares, 2011, p. XI).

The foreign domination of its past has forged Sardinia's lengthy history as an offshore part and periphery of a mainland state (Baldacchino \& Royle, 2010, p. 140), described, throughout the centuries, as a "forgotten" (Steinitzer, 1924) island on the geographical and cultural edge of Europe that remained for a long time untouched by its "civilization." Since many literary works about this island could be read as a projection of interior fears and desires of Otherness, it is proper to argue that the construction of a Sardinian discourse is "an imaginary construct in conflict with the porous nature of island reality" (McCusker \& Soares, 2011, p. XIII). This paper aims to give an account of the discourses through which Sardinia has been depicted in German-language literary works, in order to highlight, in a diachronic perspective, the construction of the island's image that has been more or less influenced by a Eurocentric and colonial point of view. The story of the colonial relationship which binds Sardinia to the Italian mainland has a different path from the relationship established with 'traditional' colonies in Africa and deserves a separate discourse that cannot be addressed here. Let us just briefly remember that it has been defined in recent studies as "semi-colonial" (Wagner, 2011, 2008). 
When read in a postcolonial context, analysis of the literary discourse on specific themes, such as the particular relationship recorded by German-speaking authors between human beings - either natives or 'foreigners' — and the Earth—alternatively described as 'rough', 'wild', 'inhospitable', 'oniric' and 'supernatural'-is relevant for the construction of the image of the island. Geopoetics has allowed these aspects to be put into evidence, by providing an analysis that brings nature and culture, Earth and man together, in the tradition advanced by Kenneth White: "It's not a question of building a system, but of carrying out, step by step, an exploration, an investigation, of situating oneself, as far as the point of departure, somewhere between poetry, philosophy and science" (White, 1994, p. 12, my translation). As is well known, such an "exploration" has been put into practice by Federico Italiano (2009) in order to "establish differences and congruities between the literary island and its supposed original" (Graziadei, 2011, p. 168). By geopoetic approach, we refer to the hermeneutic process capable of outlining an author's "territorial intelligence, his/her imagining and poetic faculty to elaborate and to construct the world, his/her particular individualization and representation of the link, of the relation between mankind and Earth" (Italiano, 2009, p. 27). In this sense, the analysis of the language through which the image of Sardinia was built over centuries could be useful in order to underline not only the island's colonial past, but also possible "anomalous images of the neocolonial project" such as uncontrolled urbanization and industrialization, mass-tourism and (nuclear) pollution (McCusker \& Soares, 2011, p. XV).

The remarkable German-language literary corpus on Sardinia warrants a separate survey. Ever since the 17th century, several Germanophonic authors have published travelogues, diaries, poems, novels, and short stories set on the island. The reasons for what could be defined as Germany's cultural islomania may find its origins in the desire and nostalgia ('Sehnsucht') for southern countries, both influenced by discovery journeys dating back to the 19th century and by the tradition of the Robinsonade (Bieber et al., 2009; Fohrmann, 1981; Stach, 1991). The renowned writer Ernst Jünger refers indirectly to the latter when he states, "In order to determine [what must be regarded as an island] a decision must be taken, a spiritual encirclement, as performed by Robinson, when he had climbed the highest peak of his loneliness and saw himself surrounded by the sea" (Jünger, 1957, pp. 335-336, my translation). On the other hand, the relevance of the island in the tradition of the Grand Tour is to be excluded, since the latter is associated with a cultural formation and education from which Sardinia-considered as an 'uncivilized' edge of Europe- - has always been excluded.

Since there are few scientific studies focusing on the specific case, it is clear that the singular fascination of German writers for Sardinia — unparalleled in other literatures — calls for a thorough investigation, which cannot be accomplished in this paper. Thus, the analysis of some themes and features of a number of works from the above cited corpus is to be regarded as one of the first steps (Serra, 2015, 2014) in shedding light on an issue that certainly requires further investigation.

\section{An island on the edge of Europe}

From the second half of the 17th century onwards (the first travelogue that clearly cites Sardinia was published by Hieronymus Welsch (1659), many German-speaking authors landed on this island while travelling across the Mediterranean Sea. They described it as a wild and primitive world apart, geographically close to Europe but still far away from its civilization (see Fues, 1780, and Steinitzer, 1924, to cite but a few). Throughout the centuries, the island was still considered as an unknown world within the European geopolitical borders, an outpost of the dark and mysterious African continent, as demonstrated by an expedition to Sardinia organized by the then-young, famous botanist and explorer Georg August Schweinfurth (1884) (Mon excursion à travers l'île de Sardaigne), who lived from 1836 to 1925. Thanks to its physical extension and its varied geophysical formation, its endemic flora and fauna, its climatic and cultural - particularly linguistic - varieties, Sardinia has often been described as a continent apart, a sort of mysterious and unexplored world which, still in the 20th century, had yet to be discovered. 
The first work dealing extensively with Sardinia is the collection of thirteen letters entitled Nachrichten aus Sardinien (1780), which, in accordance with the literary tradition of the time, were sent by an anonymous author (alias Joseph Fues, Chaplain of the German Infantry Regiment von Ziethen) to an unknown German Baron. The declared intention for such an enterprise was "to let you know how much I have been so far informed of a country, which is little known even by its own inhabitants" (second letter, my translation). The author assumes that readers will probably be "astonished by the fact that in our civilized Europe there could exist such a miserable constitution as Sardinia has" (dedicatory letter). Starting from the first letter, the author compares Cagliari a "city made of stones," with the particular customs of its inhabitants and stigmatizes it as "strange" and "singular" (first letter) to a "stranger coming from the northern regions" (first letter): "Already from afar, Cagliari does not appear so inviting because of its position on the bare rocks; and when one sets foot on land, one finds a people who, in their dress and customs, astonish the stranger" (first letter). Elsewhere in this epistolary travelogue, the indigenous population is described as "lazy," "arrogant," "lusty," and "extremely revengeful" (third and thirteenth letter), with an evident Eurocentric and philo-Piemontese attitude which could find explanation in the German Chaplain's Protestant beliefs (for example, a tendency to judge the particularities of the locals' Catholic faith by underlining the traces of a pagan legacy). Although these letters had a very limited print run and could not be widely read in German-speaking countries, they started to catch the attention and interest of intrepid soldiers, travellers, and adventurers, who were fascinated by the image of such a wild and dangerous island.

This is the case of Wilhelm Lück's (1831) Der teutsche Sergeant unter den Sarden (The German Sergeant amongst Sardinians), the adventure story of a 22-year-old soldier from Weimar, who was captured in Spain and then forced to serve the House of Savoy in Sardinia. And again, the travelogue Durch Sardinien (Meissner, 1859), whose author Alfred Meissner narrates the adventures and encounters of a long journey that comes to an end on the island. In a more specific way than Fues, the narrator depicts the island landscape as occupying a particular dimension between wakefulness and sleep and characterizes the major Sardinian town as being "melancholy" and frightening:

The town [Cagliari] with its castle walls, the strangely ragged mountains, the wide lagoons, shining with the reflection of the evening sky, offered a desolate and sad, but magnificent framework. It was strange to me and I scarcely knew whether I was dreaming or awake. The sky had an uncanny, gloomy redness, as if from a widespread conflagration. It was an African heaven, no longer an Italian one, and filled the mind with melancholy and fear. (Meissner, 1859, pp. 157-158, my translation)

A geopoetic approach can be used to analyze this description, since the author mentions several geoecosystemic spheres associated with the melancholy, which, as we will see, was to become one of the peculiar features of the island for German-speaking authors. The depiction of the town takes into account elements from the anthroposphere (in connection to the lithosphere, with the "castle walls"), the pedosphere ("strangely ragged mountains"), the hydrosphere ("wide lagoons"), and the atmosphere ("the evening sky" with "an uncanny, gloomy redness") reflected in the lagoons. All these elements contribute to creating what the narrator defines as a "sad but magnificent framework" which, caught in a moment between sleep and wakefulness, causing his special mood of melancholy and sadness. The picturesque element is, in fact, given by both the appalling and frightening feelings coming from the reddish sky (mirrored in the lagoon) which is associated with a "conflagration" and uneasiness offered by a "foreign" African and "not Italian" sky. Such a geopoetic analysis is confirmed later on in the narration, as many aspects of the island's social life are depicted as "terrible" and "uncanny" (Meissner, 1859, p. 155), in a hegemonic and colonial discourse about the island.

A geopoetic approach can also be of help in analyzing the works of the famous linguist Max Leopold Wagner, who went to Sardinia in 1904 with the aim of becoming more familiar 
with the object of his linguistic studies, namely the peculiar varieties spoken on the island. On his trip, Wagner looked for what he calls the "genuine" Sardinia, the innermost regions of the island, less "contaminated" by foreign cultures, an island within the island. This experience gave him the opportunity to write a scientific essay about Sardinian popular poetry (Wagner, 1906) in which he theorizes a deep correspondence between natural landscapes, culture, and the character of the islanders in a convincing rhetorical discourse that contributes to the construction of a specific image of Sardinia. Wagner furthers this hypothesis in a series of articles published in Globus. Illustrierte Zeitschrift für Länder- und Völkerkunde in 1907-1908 and in Deutsche Rundschau für Geographie in 1913-1914. On visiting the village of Macomer, located in the centre of the island, Wagner describes the perfect union binding the indigenous population to Nature, exemplified in the melancholic folksong called 'Mutu':

I remember how clearly this combination between the character of the population and the landscape came to me when we visited the Nuraghe Santa Barbara near to Macomer. We descend goat tracks from the dark, high-lying village down to the bed of a small mountain stream, and from there again upwards and then through thistles and thorns to the memorable edifice of a grey, prehistoric time. All round is rock, the river bed suddenly becomes solidified granite, grey and heavy. On the other side of the brook, the railroad runs down the rocky path to Nuoro. We were just looking down onto this gloomy, seemingly deserted valley, when suddenly the plaintive sounds of an elongated and slightly tremulous Mutu rose up to us from the bottom of the valley. We saw the singer, a girl washing the laundry in the stream. The melancholic singing resounded shrill from the steep sides of the mountain, and the last verses resounded even more acutely; then everything fell silent to the deepest hush. In this Nature, the Mutos have an unspeakable charm, and through it, one learns to understand them. (Wagner, 1906, p. 264, my translation)

The detailed description of the landscape close to Macomer is made up of perfectly intertwined geospheric elements. The author describes his way to the megalithic building of Santa Barbara, in a descending movement - which evidently follows an ascending one, not described in the text after which there is a new ascent; these movements allow him to come into physical (he descends the country path), visual (he observes the village, the mountain, the valley), tactile (he feels the thistles and the thorns), and auditory (he hears the traditional folksong) contact with Nature and to understand the perfect combination ('Zusammenhang') between the Earth, humankind, and culture. Through the biosphere of a country path disseminated with "thistles and thorns," Wagner describes the anthroposphere (the "dark, high-lying village") and gradually approaches elements of the (dried) hydrosphere ("the bed of a small mountain stream") and the lithosphere ("all round is rock"). The rocky elements seem to dominate this landscape: not only is the ancient building made of large stone blocks, whose positioning is still hard to understand, but the hydrosphere has also become stone, as it has dried into a "suddenly solidified granite, grey and heavy." The lithosphere seems to have invaded both the pedosphere and the anthroposphere and the railway is described as a "rocky path." From the top of the hill, the author's glance now dominates the "gloomy, seemingly deserted valley" when the anthroposphere, represented by the female voice of a girl singing a "slightly tremulous Mutu" interrupts the silence of the apparently deserted valley breaking through the air. The folksong enables the traveller to understand the harmonious interpenetration of landscape, Sardinian culture, and the character of its inhabitants.

Wagner goes further and explicitly suggests the intimate identification between Nature and the indigenous people through what is defined as the 'typical' islander's mood:

One can hardly imagine anything more melancholic than the melody of these Mutos. But this is connected with the character of the Sardinians, and this again with the 
landscape. [...] This nature is melancholic, and from it the Sardinians of the interior get, in large measure, their harsh character, which so much differs from the animated nature of the other southern peoples. (Wagner, 1906, p. 264, my translation)

The geophysical description of this Sardinian region, an island within an island, becomes a particular hermeneutic moment, in which the author grasps a unique relationship between the Earth and mankind by interconnecting the different spheres of the geosphere. The above-cited act of ascending, descending, and again taking an ascending path to reach the Nuraghe could also be read metaphorically, as the necessary difficult progress the author has to accomplish to penetrate the island's nature and its people's character. Furthermore, the Nuraghe is the symbol of a glorious, ancient past, when Sardinians were masters of their destiny and free from every foreign colonization. The mere existence of those remote times of freedom may be the cause of the people's rooted inclination to melancholy (Serra, 2015).

In this metaphorical interpretation of physical progress towards a profound understanding of the island, Wagner is literally translating an experience that he actually lived and which, to a certain extent, matches with the topography of those places he would go on to describe in the travelogue he published some years later (Wagner, 1908). This goes some way to confirming the construction of a literary discourse on Sardinia, since, over the decades, many German-language works would offer manifold variations of the correspondence between the Earth and mankind.

This is the case of the novel written by Thomas Münster (1960), Die sardische Hirtin, whose main character is a former Garibaldinian fighter who, sent to the island in 1861 as a primary school teacher, becomes the promoter of the slow and complicated process of the island's assimilation to the new-born Kingdom of Italy. The school teacher is charged with the "mission" to bring the "the fruits of European culture" to the "primitive" islanders (Münster, 1960, p. 10, my translation), but it is only with great difficulty that he manages to teach the population his contempt for rustling and the code of revenge. Both main characters (the teacher, on the one hand, and the local population, on the other) experience a process of maturation, which becomes, at the end of what is to be considered a Bildungsroman, mutual understanding and acceptance (Serra, 2014).

However, there are several moments of tension, misunderstanding, and rejection, which are overcome by the teacher's experience of a direct relationship with nature. If in Wagner's work this unique contact with the Earth affected the local population and was exemplified by the deep melancholy of the popular songs, in Münster's novel it is the protagonist himself, the foreigner representing the continental cultural authority, who achieves a perfect symbiosis with Nature in a condition of absolute solitude. The absence of the local population becomes a necessary condition for achieving this spiritual communion with the island:

At the peak of Bruncu Spina there is peace. I have ascended there, where no human beings are. [...]. For a long time I sat quietly there, and I thought I felt the sea wind blowing from the east coast, a sharp sea wind, which let me breathe again. I looked across the mountains, I saw the sea in the East, and the broad plains in the West; I saw Sardinia beneath me, with no people, and I realized that it was splendid. [...] If there were no people down there, one should have to dive in these forests, sleep in those caves, chase the boars, the mouflons, the screaming eagles - one should, one would, one could, but one cannot. For the people down there, these completely unusual and incomprehensible people, are certainly there. (Münster, 1960, pp. 75-77, my translation)

In this passage, the geopoetic analysis highlights a process-which is only partially accomplished and only partially desired-of interpenetration between man and Earth. After ascending to one of the tallest peaks on the island, the narrator enjoys a singular landscape, where the total absence of the islander is the condition sine qua non for understanding and enjoying its beauty. From above, he enjoys the atmospheric and hydrospheric elements, such as a "sharp" sea 
wind blowing from the East which allows him to feel at ease. A mere glance at the hydrosphere and the pedosphere, the sea and the "broad plains," evokes a sense of happiness and freedom, so that the narrator admits, for the first time since his arrival, that the island is splendid. It is therefore only in the anthroposphere, because of the mere existence of the islanders, that the narrator cannot experience complete interpenetration or direct contact with nature (he dreams of "diving" into the forest, sleeping in caves, and hunting the local fauna).

Two elements, in particular, distinguish this piece of literature from Wagner's scientific work: while the latter describes an ascending and descending pathway which could be read as a metaphor for the desire to come into contact with nature and to point out the particular relationship between the Earth and the local population, the former gives voice to the feelings of the narrator, who is here invested with the power of a foreign, hegemonic culture, caught in its relationship with nature. From the top of the mountain he enjoys a dominant perspective; he takes visual possession of the island, and claims also by expressing his intimate desires a privileged relationship with it. Islanders are seen here as a disturbing, negative element.

\section{Island mythic transfigurations and present-day postcolonial discourse}

As Münster's novel shows, during the 20th century many German-speaking authors emphasized the special relationship that the traveller himself, representative of a continental world, establishes with the island. In these cases Sardinia becomes a metaphor for the general possibility for mankind to recover a strict and genuine relationship with Nature. This literary topos still has echoes in present-day production and conveys a mythical and dreamlike aura to the island so that it often becomes the ontological representation of islands in general, the privileged cosmic dimension where life originated and to which humankind should necessarily return.

The most famous author who wrote unforgettable lines about Sardinia and other smaller nearby islands is certainly Ernst Jünger. Although it is not possible within the confines of this paper to analyze in depth the concept of islands and archipelagos in Jünger's complex work, it is worth underlining that his stays on Sardinia are closely connected with his theories of a human longing for eternal homecoming and with his refusal of modernity, which prevents human beings from achieving a direct connection with the universe. More than any other works, the diary Am Sarazenenturm (Jünger, 1955) and San Pietro (Jünger, 1957) describe Jünger's Sardinian experience as a "Pilgerschaft," a "pilgrim's progress" (Jünger, 1957, p. 357), a "Bildung" (Schramm, 2008). The author tries to fulfill the "highly complex task" (Jünger, 1957, p. 335) of defining the very concept of islands. San Pietro is a small island in the southwestern part of Sardinia. It is described as "an island to the third power," since it stretches alongside the larger island of Sant'Antioco, which is close to Sardinia itself. In turn, San Pietro is surrounded by smaller islands "like a brooding hen with her chicks" (Jünger, 1957, p. 336):

Islands are not only made of sand on the sea, but everything is an island, also the continents, and even the Earth is an islet in the etheric sea. It is therefore fitting that the island is thought of not only extensively, but also intensively; it is one of the great dream visions. [...] Insel, insula, isola, Eiland - these are words for a secret, a separate one. They evoke the idea of possession and property. (Jünger, 1957, p. 335, my translation)

Through the island metaphor Jünger traces the sense of human existence, the very revelation of happiness which can only arise from a human being's reconciliation with Nature, in a cosmic peace: "We guess long periods of peace on islands, a closed, happy life, that we can dream of here. And this is one of the great themes that have always occupied the mind" (Jünger, 1955, pp. 12-13, my translation). Understanding islands is a hermeneutic process that necessarily leads to self-knowledge: according to Jünger, Robinson Crusoe's decisive step towards knowledge consisted not so much in challenging and surviving the adverse forces of nature, but in taking consciousness of the island as an entity. Such an epiphany is as much as the contemporary human 
being could wish for in order to gain self-awareness in the world in which he/she lives: "If one day we understood the Earth in this sense, humanity would also define its boundaries according to a new quality" (Jünger, 1957, pp. 335-336, my translation).

The remarkable description of space in San Pietro is particularly well-suited to a geopoetic analysis and exemplifies the author's island philosophy. It is worth recalling the whole passage:

Only a few places on our continent still give a feeling of solitude, as one enjoys it here. Apart from the lapping waves, the only sounds one hears are the shrieking of the seagulls and the croaking of the ravens, who build their nests in the fissures of the rocks. In the rising wind currents, reddish hawks glide and turn before swooping down.

Even these voices were silent when I landed in the deeply etched valley of a rain river. Rusty red lava ribbons twisted in the upper part, falling in stiffened waves over its edges. The ground was made of white chalk, which blinded the eyes. Small and great columns rose from it. Mineral pieces lay scattered like meteorites on it. The times when the waterfalls had dug their bed here seemed infinitely distant—so arid, as if out of air, the horizon presented itself to one's glance. The objects sharpened their profile in that surreal space where there was no atmospheric but only a mathematical perspective. Even where sparse vegetation had settled, it stood in a lifeless, geometric style. Tiny salt plants spread their leaves in red and green prisms; they seemed to be engraved in the stone. Bending over them I saw their blossoms which like the wheels of a tiny pocket watch, turned to the sun. A bigger flower of the species of our daisy also adhered to the spirit of the place by raising a single bud at the exact centre of a rosette that seemed to be plotted with a compass.

The place was cosmic rather than terrestrial, far from the world. It seemed to fit into the plans in which cosmic space acts on our space, creating landing places. This perhaps includes the thoughts that affect us in such a lunar landscape; they become more crystalline like the plants. (Jünger, 1957, p. 355, my translation)

Jünger's passage focuses on a landscape dominated by stones, a blinding light and absolute silence; it is defined as "mathematical" and "geometric" since, apart from some references to the biosphere, it seems to exclude every form of life. The landscape described, however, opens a profound cosmic richness to the reader and reveals some traits of the author's complex philosophy. Numerous elements of the geosphere contribute, in "surreal" harmony and in perfect balance, to a dimension of immobile solitude: the very rare elements of the hydrosphere ("the lapping of the waves") and the biosphere (the shrieking of the seagulls and the croaking of the ravens) melt, liquefy in the lithosphere and seem embedded in a rocky landscape. The birds, gliding and turning in the atmosphere ("in the rising wind currents"), nest between the rocks; the valley is characterized by a petrified hydrosphere of impetuous waves of lava; pieces of mineral look like meteorites fallen from the sky, and the river bed, covered with chalk, blinds one's eyes. Jünger describes a space made of stone, whose geometric perfection is even perceived in the rare vegetal elements (weird grass and small flowers) which, more than being a symbol of natural life as they turn towards the sun, are the subject of mathematical speculation; their formal perfection calls to mind a watch and a compass. The narrator enjoys the immobility of space and time, in an atmospheric rarefaction which takes away his breath; his experience contrasts with the sense of liberation perceived by Münster's character, as he recovers a sense of freedom in direct contact with the wild Nature without any indigenous human presence.

In Jünger's work, this representation is to be regarded as anything but negative: space is defined as "cosmic," "surreal," and "lunar," and this is also true from a chromatic point of view (the predominant colours of this landscape are "reddish" - the birds and the lava — and white - the "white chalk"). It offers the possibility of a safe haven for human thoughts which thus become clear and crystalline. The voyage to the island is described as a pilgrimage in the sense of 'Bildung'; 
Jünger's theory considers islands as a cosmic "home" with mysterious languages, from which mankind can still benefit through the intuitive enjoyment called "happiness":

Islands are home in the deepest sense, the last earthly seats before the cosmic journey begins. Language cannot do them justice, it is rather a song of fate that sounds out over the sea. Then you let go of the wheel; you would like to go aground on this beach. What are man's thoughts before these lotus flowers in the blue sea? (Jünger, 1955, p. 124, my translation)

Sardinia's literary discourse, to which Ernst Jünger's speculations have certainly made a considerable contribution, is nowadays the subject of a series of contemporary works on this island, which help to analyze its complex postcolonial reality. The charming land, whose unspoilt nature allows a direct relationship between mankind and the Earth, turns out to be a mirage, a projection of rather impossible wishes and ideas in the travelogues and novels by Godehard Schramm (Sardinien, 1983), Markus Fritsche (Die Rückkehr, 2011), and Hans-Ulrich Treichel (Mein Sardinien, 2012). In Sardinien, Schramm directly and indirectly quotes Jünger's masterpieces and island experiences, but attempts to convey a more realistic image of Sardinia by balancing its poetic transfiguration with disenchanted descriptions of an industrialized, polluted, and desertified land (Schramm, 1983, pp. 113-114), with an emphasis on the continental and hegemonic perspective:

It is sometimes as if one were sitting on a first-class train with German standards, and at a bend one sees the last carriages, the Sardinian ones, which are still only Third Class - and since, in a singular way, whatever the difficulties, they still go on, we sometimes look back fondly from the Comfort Class at these others. (Schramm, 1983, p. 105, my translation)

The present-day island discourse depicts a reality caught between past mirages and the problematic postcolonial present and is exemplified by Markus Fritsche's novel Die Rückkehr (2011). This is the story of a Sardinian emigrant who, sentenced to death by an incurable disease, decides to make a last journey from Germany to his homeland, in the secret hope that contact with his beloved island could cure him or, at least, ease his pain. One of the most interesting and innovative features of this novel is the attempt to depict present-day Sardinia as a beautiful but nevertheless "sick" reality, which mirrors the protagonist's illness. Fritsche clearly states how the ancient, traditional integrity of the island has been taken over by tourism, pollution, and the military 'occupation' of the NATO bases:

High Potent Uranium, which could only come from the US military base lying on the La Maddalena peninsula. Submarines with nuclear warheads were stationed there. (Fritsche, 2011, p. 72, my translation)

The impact of mass tourism in Sardinia was also like an attack. A splinter bomb that tore something fundamentally compact into tiny parts. A sneaky assassination attempt on one of the last grandmothers of the European West. A grandmother who still had time to trust nature unconditionally, a grandmother who watched the millennial traditions and the rhythm of life of a people who had always lived outside, never surrendering to the tenth-of-a-second achievements of a civilization that always wanted to be faster. With his faith in the pure healing power of the island, Matteo was a few decades too late. (Fritsche, 2011, p. 106, my translation)

The island is here personified as a benevolent ancestor that cares for the 'pure' and 'genuine' Western traditions and which today is endangered by the destructiveness of modern lifestyle. If 
Sardinia was once derogatorily defined as an island at the borders of European civilization, in Fritsche's words, this isolation makes it the custodian that safeguards this selfsame civilization from the evils of modernity. The island, however, has not been preserved from corruption and if, at the beginning of the novel, the protagonist Matteo still believes that it could heal his soul and his pains, in the end he becomes painfully aware of how Sardinia has irredeemably changed with mass-tourism, pollution, and military bases. He therefore decides to rebel against the present forms of 'colonization' by planning to bomb Berlusconi's villa on the Emerald Coast, the blatant symbol of new forms of exploitation and corruption.

The last work to be considered in this discussion is the novel Mein Sardinien (2012), an ironically metaliterary work on the very construction of Sardinia in island discourse itself, written by Hans-Ulrich Treichel. Against the background of an autobiographical experience, the narrator plays with Sardinia's absence in the tradition of the Grand Tour ("However, I had never considered Sardinia. But Sicily. Sicily also belonged to Goethe's travel route. But not Sardinia. Sardinia nostalgia was completely new to me. And not just to me" [Treichel, 2012, p. 29, my translation]) and also with foreign travellers' islomania, so that he starts to collect, and to cite, a series of literary works about this island, with the aim of getting acquainted with the 'Sehnsucht' and the mirage of the island's 'primitiveness'. When he arrives in Sardinia, the narrator's mind is full of literary (and second-hand) images, so that he is extremely disappointed with every comparison with reality:

The bus ride and what I saw outside were monotonous enough. A crooked street, grey unpolished dwelling-houses, warehouses, garages, from whose flat roofs rusty rods poked out. Plastic bags full of rubbish on the roadside. Dusty front gardens. No cypresses, no pines, no olive groves. And nowhere a view of the sea. (Treichel, 2012, p. 53, my translation)

The island's 'Sehnsucht', so philosophically and poetically expressed by Ernst Jünger, falls short when Treichel has to face common reality in the most distant province, in the south of the south, in the small town of Carbonia, which is not even lapped by the sea. Treichel's narrator acknowledges the existence of 'another' less poetic island, far from the insular discourse built over the centuries: "No South. No cypresses. No pine trees. No palazzi. And also no sea" (Treichel, 2012, p. 51, my translation).

\section{Conclusions}

Over the centuries, German-speaking authors have contributed to the construction of a literary discourse on Sardinia which, on the one hand, has confirmed a strong desire for exoticism in the form of curiosity and fear towards the Other and, on the other, the need for a cultural appropriation of an island on the edge of Europe. In light of the construction of such a discourse, it has been possible to underline, through a geopoetic analysis of texts, the relationship between humankind and natural elements, which German travellers and writers have defined as peculiar to Sardinia. In this sense, it has sometimes been possible to enucleate a hegemonic and colonial discourse that, in the course of the 20th century, has created images that are a transfiguration of the island as a dreamlike dimension in which to retrieve a direct, intuitive relationship with the cosmos and as a metaphor of the ontological essence of the island itself.

It is only in the last decades that this discourse has been confronted with a critical and disenchanted representation of Sardinia, where German-speaking writers also point out the traits of a postcolonial reality through the denunciation of issues such as urbanization of the coasts, pollution, and the loss of cultural traditions through mass tourism phenomena. Finally, in the most recent literary production, the object of speech is no longer the ontological dimension of the island, but the same discourse built around it, where literary transfiguration corresponds to the disenchanted representation of a reality whose problems do not differ from those of other regions in the world. 


\section{References}

Baldacchino, G., \& Royle, S.A. (2010). Postcolonialism and islands: introduction. Space and Culture, 13(2), 140-143. https://doi.org/10.1177/1206331209358229

Bieber, A., Greif, S., \& Helmes, G. (Eds.) (2009). Angeschwemmt-Fortgeschrieben. Robinsonaden im 20. und beginnenden 21. Jahrhundert. Würzburg: Königshausen und Neumann.

Brunner, H. (1967). Die poetische Insel. Inseln und Inselvorstellungen in der deutschen Literatur. Stuttgart: Metzler

Dongu, M.G. (Ed.) (2012). Con parole altrui. La Sardegna nella cultura europea. Cagliari: CUEC.

Fohrmann, J. (1981). Abenteuer und Bürgertum. Zur Geschichte der deutschen Robinsonaden im 18. Jahrhundert. Stuttgart: J. B. Metzler.

Fritsche, M. (2011). Die Rückkehr. Oldenburg: Schardt Verlag.

Fues, J. (1780). Nachrichten aus Sardinien von der gegenwärtigen Verfassung dieser Insel. Leipzig: Sigisfried Lebrecht Crusius.

Graziadei, D. (2011). Geopoetics of the island: strategies against iconic isolation. In F. Italiano \& M. Mastronunzio (Eds.), Geopoetiche. Studio di geografia e letteratura (pp. 163-181). Milano: Unicopli.

Italiano, F. (2009). Tra miele e pietra. Aspetti di geopoetica in Montale e Celan. Milano: Mimesis.

Jünger E. (1957). San Pietro. In Sämtliche Werke. IV (pp. 335-370). Stuttgart: Klett-Cotta.

Jünger, E. (1955). Am Sarazenenturm. Frankfurt a.M.: Klostermann.

Lück, W. (1831). Der teutsche Sergeant unter den Sarden oder Aufenthalt eines Großherzoglich Sächsisch Weimarischen Militairs in Sardinien vom Jahre 1810 bis 1817. Leipzig: Köhler.

McCusker, M., \& Soares, A. (Eds.) (2011). Islanded identities: constructions of postcolonial cultural insularity. Amsterdam \& New York: Rodopi.

Meissner, A. (1859). Durch Sardinien. Leipzig: Herbig.

Münster, Th. (1960). Die sardische Hirtin. Berlin, Darmstadt, Wien: Deutsche Buch-Gemeinschaft.

Schramm, G. (2008). 'Wunderbare Augenblicke'. Ernst Jüngers unerschöpfliche 'Sardische Heimat'. Zibaldone. Zeitschrift für italienische Kultur der Gegenwart, 46, 61-78.

Schramm, G. (1983). Sardinien. München: Süddeutscher Verlag.

Schweinfurth, G.A. (1884). Mon excursion à travers l'île de Sardaigne 1858. In W. Barbey (Ed.), Florae sardoae compendium (pp. 125-169). Lausanne: Bridel.

Serra, V. (2015). 'Questa natura dispone alla malinconia'. Paesaggio e carattere della Sardegna nell'odeporica di lingua tedesca. In M. Tanca \& S. Aru (Eds.), Convocare esperienze, immagini, narrazioni. Dare senso al paesaggio (pp. 85-97). Milano: Mimesis.

Serra, V. (2014). Barbarenland-Überirdisch schmerzende Magie der kosmischen Schönheit. Immagini e miraggi della Sardegna nella narrativa di lingua tedesca. Letterature Straniere E. Quaderni del Dipartimento di Filologia, Letteratura, Linguistica dell’Università di Cagliari, 15, 259-273.

Stach, R. (1991). Robinson und Robinsonaden in der deutschsprachigen Literatur. Eine Bibliographie. Würzburg: Königshausen und Neumann.

Steinitzer, A. (1924). Die vergessene Insel. Gotha: Der Flamberg Verlag.

Treichel, H.U. (2012). Mein Sardinien. Hamburg: Mareverlag.

Wagner, B. (2011). La questione sarda. La sfida dell'alterità. Aut aut, 349, 10-29.

Wagner, B. (2008). Sardinien. Insel im Dialog. Texte, Diskurse, Filme. Tübingen: Narr Francke.

Wagner, M.L. (1908). Reisebilder aus Sardinien. Temotal, Macomér und Tirsotal. Globus. Illustrierte Zeitschrift für Länder- und Völkerkunde, 94, 71-76.

Wagner, M.L. (1906). Die sardische Volksdichtung. Festschrift zum 12. Deutschen Neuphilologentag. Erlangen: K. b. Hof- u. Univ.-Buchdruckerei von Junge u. Sohn, 236-288.

Welsch, H. (1659). Warhafftige Reiß-Beschreibung [...]. Nürnberg: Endter.

White, K. (1994). Le Plateau de l'Albatros. Introduction à la géopoétique. Paris: Bernard Grasset. 